\title{
The Making of Tourism Film as an Instagramable Promotion Media in Harian Boho District, Samosir District
}

\author{
Samerdanta Sinulingga \\ Universitas Sumatera Utara, Indonesia \\ danta@usu.ac.id
}

\begin{abstract}
Technology development has a major role in tourism growth in Indonesia. One of these technology products is Instagram. Instagram has been recognized worldwide as a platform that can give dominant influence on increasing product sales and increasing tourist visits to a tourism destination. This Instagram has 3 main content as a channel of information to society, namely video content, photos and written content. This is what wants to be tested experimentally in the Lake Toba region, especially in the Samosir Regency, the Harian Boho District. The initiation of this research was carried out not only as a copyright work, but through this research it can be understood the effectiveness of using films for promotional purposes on Instagram on its impact in increasing tourist visits to a tourism destination during the COVID-19 pandemic. The method that is used in this research is descriptive qualitative phenomenology with data collection techniques, namely snowball sampling. The results of this study found that publishing travel promotion films through social media Instagram turned out to have a very significant impact in increasing tourist visits to a destination. It was recorded that after publishing the film, the increase in tourist visits reached 1,648 visits (August 2020) even though in the previous month there were only 22 people recorded. From this experiment, it is proof that Tourism Promotion Films have significant influence on increasing tourist visits during the COVID19 pandemic.
\end{abstract}

Keywords

Instagram promotion; tourism destination; tourismfilm Lake Toba

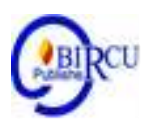

\section{Introduction}

The Lake Toba area has now become a Super Priority National Tourism Strategic Area (KSPN) for Indonesia. Lake Toba itself is managed by 8 districts with 32 sub-districts, one of which is in the Boho Daily District, Samosir Regency. This location has the potential for natural and cultural tourism that is as unique as other areas around the KSPN area, and the weakness is the same, namely the lack of tourist visits to that location (Siregar, 2018). Knowing this weakness, the government-held many big events in the KSPN area, be it cultural tourism events, 1000 tents, and so on; but this activity has been criticized by the Indonesian Tourism Industry Association (GIPI) because this event is just like a regional cultural festival, where the organizers are local people, most of the art actors are residents,

The problem of poor management and the impact of this tourist event on international tourist visits has not yet been resolved, the dilemma has peaked when the issue of the coronavirus spreads in various parts of the world which resulted in a drastic decrease in foreign tourist visits (OECD, 2020). Until now, governments around the world are making improvements to the disaster that has occurred, but it must be acknowledged that the situation 
regarding the coronavirus is gradually showing significant improvements (World Tourism Organization, 2020).

Technically, many things can be done to promote the return of tourist visits to destinations throughout Indonesia. One of them is using film (Sinulingga, 2020). This technique is currently being carried out by the State of Singapore, in controlling the effects of the corona issue, whose impact is not only on health issues but also affects the country's economic / investment climate.

It must be admitted that film and tourism during the industrial revolution 4.0 had a strategic function in influencing market confidence in the destination tourist sites (Beeton (2010) and Suryajaya (2018)). This is by Hudson's (2005) research which found that films and tourist visit rates have a close relationship:

Table 1. The Impact of Films on Tourist Visits

\begin{tabular}{|l|l|l|}
\hline \multicolumn{1}{|c|}{ Film/TV Series } & \multicolumn{1}{c|}{ Location } & \multicolumn{1}{c|}{ Impact } \\
\hline Braveheart & Wallace Monument & release
\end{tabular}

Source: Hudson, S., Ritchie, JB (2005)

The picture above explains that films can have an impact on increasing the number of tourist visits to an area.

The Boho Daily District is located on the coast of the Lake Toba region, which is one of the areas in the Super-Super Priority National Tourism Strategic Area (KSPN), this area has various tourism potentials starting from 1) Natural attractions, namely Efrata Waterfall and Janji Martahan and 2 ) Cultural attractions, namely the houses and the Toba Batak people. With the central government's target of creating 10 new Bali in Indonesia, the Super Priority National Tourism Strategic Area (KSPN) is a government effort to create a quality tourism concept (Siregar, 2018).

The concept of quality tourism currently in government standards consists of 5 forms, each of which can stand independently, namely foreign exchange and tourism added value, destination readiness, human resource capacity, environmental carrying capacity, and the image of tourism that is competitive in the archipelago (Government of Indonesia, 2015). Among these 5 categories, the exact specification in this study is the development of an image of tourism that is competitive in the archipelago by making tourism films to create quality 
tourism. The government's focus point categorizes Lake Toba as a Leading Destination (Siregar, 2018). So this research becomes very relevant to be carried out in the core zone of Indonesian tourism development. to see how the right form is in presenting information on areas with a very large nuance of geodiversity and culture diversity so that the image of Indonesian tourism competitiveness which is the current target of the Ministry of Tourism can be achieved. In Film and Tourism, the involvement of local communities is needed, the context of small and medium entrepreneurs is facilitated because what will be done later is to promote the tourism products they have, and finally the equitable distribution of tourism development can also be achieved if the level of tourist visits increases later to the Boho Daily District.

\section{Review of Literatures}

\subsection{Definition of Tourism}

The technical function of the theory, in this study: According to Law Number 10. In the year 2009, there are $3 \mathrm{key}$ indicators related to tourism, namely: 1) tourism activities, 2) tourism facilities and 3) tourism services from stakeholders.

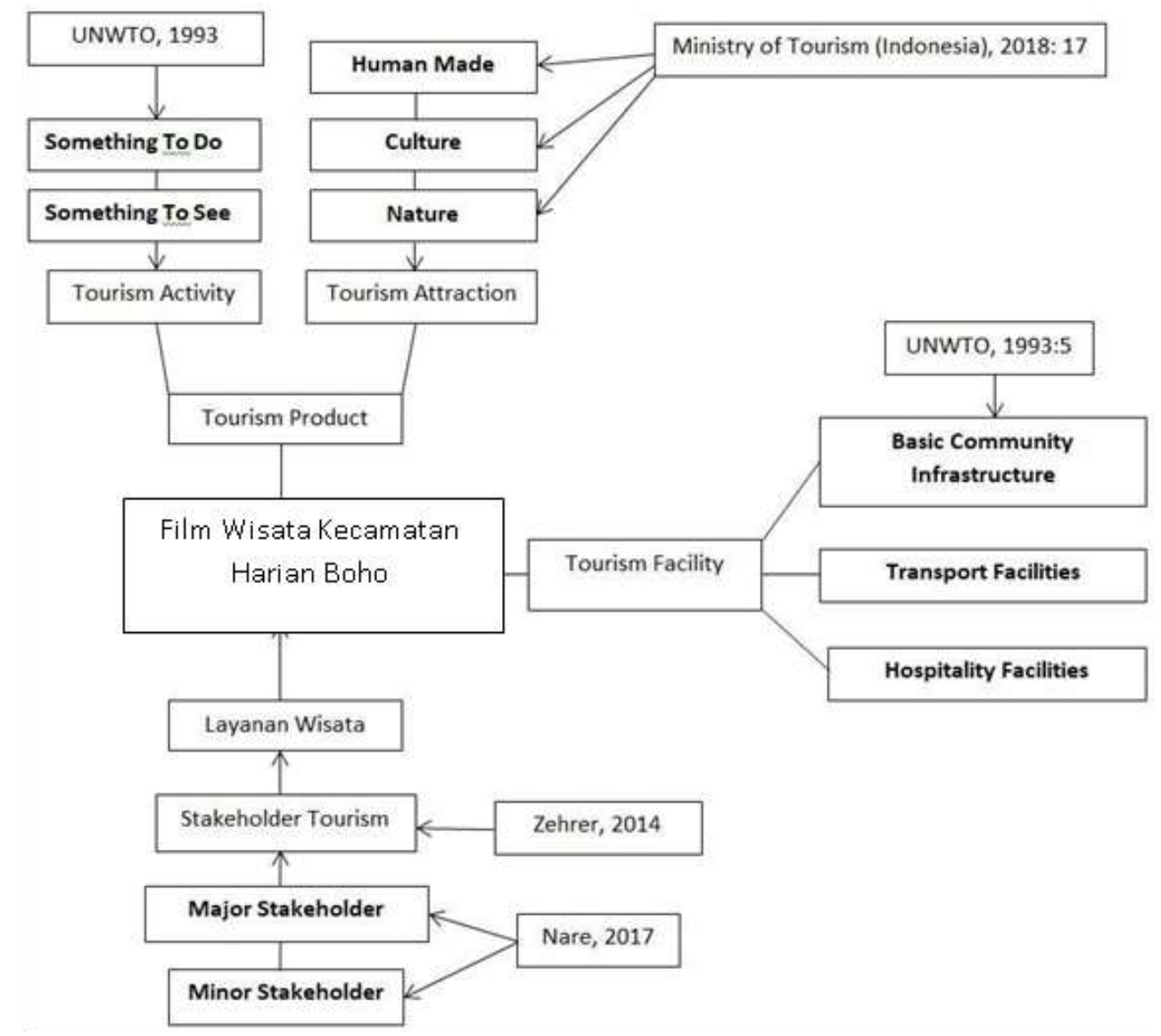

Figure 1. Tourism Definition Framework in Tourism Film Analysis

Tourism is an industrial sector which is currently got a lot of attention from many countries in the world. The tourism sector is believed to have the ability to increase economic growth (Maciej Debski 2013). Moreover, the tourism sector is positively encouraged to be able to replace the oil and gas sector which has been the main capital in the country's foreign exchange earnings. (Siswanto in Amin et al, 2019) 
Tourism is one of the determinants of national economic growth because it can influence the growth of other sectors in the economy (Gokovali \& Bahar, 2006) and also grows very fast during this decade (Dogru \& Bulut, 2018; Wu et al., 2000). (Welford \& Ytterhus in Nurlina, 2020).

Tourism activities according to UNWTO (1993) in Hasan (2015) are influenced by 2 things, namely tourist attractions and tourist activities. Tourist facilities according to UNWTO (1993) in Hasan (2015) have 3 types, namely basic tourism facilities, then transportation facilities, and hospitality facilities such as accommodation, restaurants, and the like. Tour services or service providers are things that are related to human resources who carry out tourism with technical equipment to support tourism.

\subsection{Understanding Instagramable Promotion Media}

The technical function of theory, in this study: According to Hasan $(2015: 266)$ there are important things that must be considered related to the content of advertisements that use film as a promotional medium, namely: 1) The color or image projected from the film is designed to attract the attention of tourists; 2) Show features that can reinforce the unique image of a tourist destination; 3) Show the multi-dimensional nature of the destination (what kinds of activities can be done at the attraction); 4) Use a ratio of $54 \%$ image display and $46 \%$ information.

\subsection{Understanding Cinematography}

The technical function of the theory, in this study:

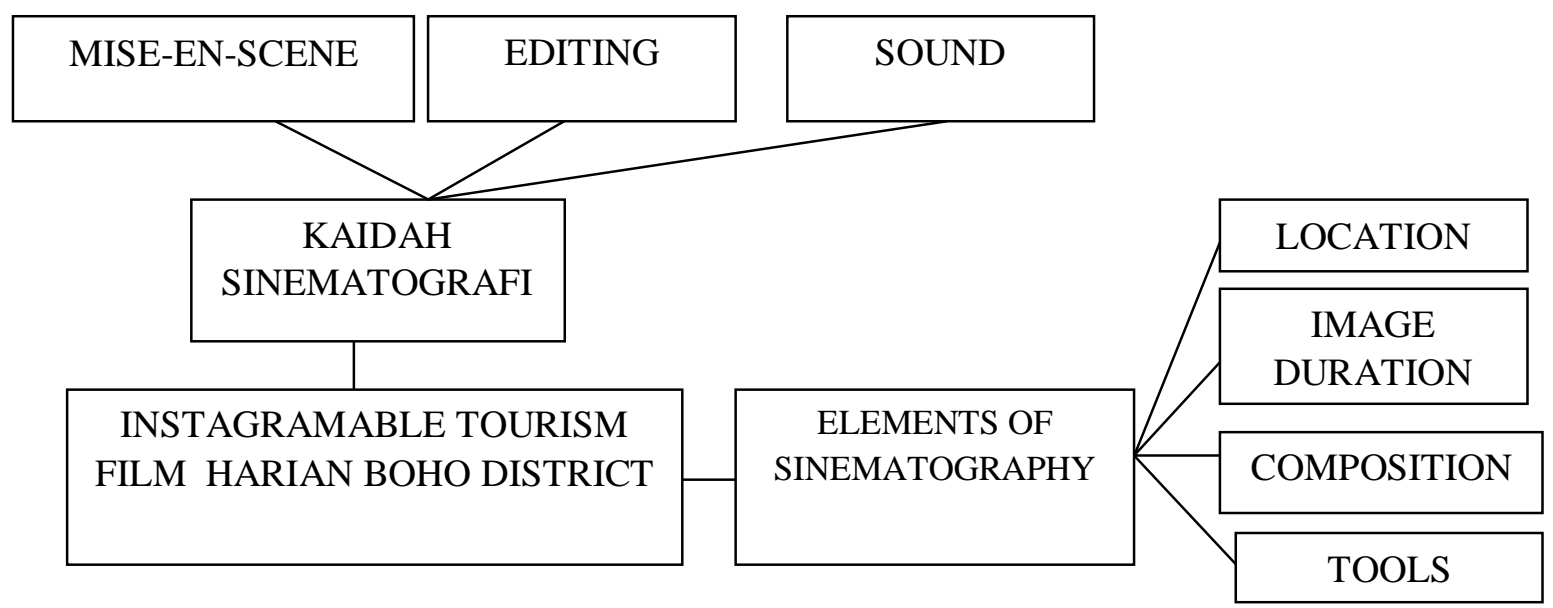

Figure 2. Cinematography Framework in Tourism Film

In the Regulation of the Minister of Home Affairs of the Republic of Indonesia Number 3 of 2017, documentation is the collection, processing, preparation, and recording of documents, data, images, and sounds for public information materials. In-Law Number 33 of 2009 , the film is a technique of capturing images and at the same time combining images so that they become a series of images that can convey ideas and stories.

There are 3 stages in film design according to cinematographic principles, namely: PreProduction, Production, and Post-Production (Brata, 2007). Post-production elements, namely: Graphic Filling, Music Filling, and Film Distribution (Irawan, 2011). To obtain cinematographic elements in the film to be produced, film actors must consider four main aspects, namely: tools (scenarios, cameras, computers, etc.), composition (shot, angle, exposure, flow, files, art, and movement), location, duration. images (Semedhi, 2011). 


\section{Research Methods}

This type of research is qualitative research, using phenomenology. The research subjects in this study were major stakeholders, namely stakeholders who have direct interests in the Boho Daily District, such as the manager of the natural baths of the Boho Daily District, community leaders, village officials, and guides. The sampling technique in this research is snowball sampling. There are 2 sources of data in this study, namely: 1) primary data sources (interviews with informants and libraries), and 2) secondary data sources (digital information/ebooks, books, laws, films/photos). This research instrument uses 2 forms: using interview guidelines and film format manuals. The observation technique uses participant observation. The data analysis technique in this study used the model of Miles and Huberman in Yusuf (2016:407), such as data reduction, data display, pull / leverage.

\section{Result and Discussion}

In making instagramable travel films in the Boho Daily District, Samosir Regency, several things must be considered, namely 1) the process of making the travel film itself and 2 ) validation which proves that the travel film made is indeed an Instagramable travel film. The process of making tourist films includes pre-production, production to post-production; Meanwhile, the validation of travel films as a promotional medium includes: film colors or images, features that strengthen the uniqueness of the image of a tourist destination, are multidimensional, and a ratio of $54 \%$ for image display and $46 \%$ for information. The complete description is written as follows:

\subsection{Tourism Film-Making Process}

There are 3 main things in the process of making tourist films in the Boho Daily District, namely film pre-production, production, and post-production. The full description is explained as follows:

Tourist Film Pre-Production

The pre-production of tourism films in the Daily Boho District starts with (1) designing the concept of tourism films, (2) determining the location of tourist films, (3) determining tourism activities, (4) preparing tourist film scenarios, and (5) preparing mise-en-scenes and (6) preparation of tour film distribution.

\subsection{Tourism Film Concept Design}

The concept plan for the tourism film which is designed in the shooting activity is a tourist activity in Boho Daily District. The tourism activities in the Boho Daily District are adventurous types of tourism with natural nuances and cultural tourism. Based on the interviews that have been conducted between stakeholders and researchers, 5 main locations for filming were selected.

\subsection{Determination of the Location of Tourist Films}

Based on the inventory of natural tourism products found in the Boho Daily District, 4 tourist attractions are determined for the shooting of the tourist film, namely: Efrata Waterfall, Tele Tower of View, Janji Martahan, Holbung Hill, and Sihotang Village. 


\subsection{Determination of Tourism Activities}

The tourism activities at these locations consist of two types of activities, namely primary activities and secondary activities. Primary activities at this tourist location are to explore nature tourism, explore cultural tourism, and man-made tourism. To explore nature tourism, activities that visitors can do such as camping, exploring villages, canoeing with fishermen on Lake Toba, sightseeing using boat transportation. To explore cultural tourism activities that visitors can do, such as: staying at the traditional houses of residents, seeing residents raising buffalo and oxen, camping on the hills, interacting with indigenous people, seeing rice planting activities to harvesting, seeing the sarcophagus (stone grave), seeing the traditional community stone fort, the ceremony to give the title or clan of the indigenous community to visitors Activities that can be done by visitors such as: seeing the view from the Tele Tower all the views on Lake Toba, especially the Boho Daily District, enjoying the travel route on Lake Toba, especially the Boho Daily District. Secondary activities at this tourist location include: seeing residents bathing buffalo, discussing with passenger boat owners, village children playing in their neighborhood, seeing fauna such as eagles.

\subsection{Preparation of Travel Film Scenarios}

The scenario for a tourism promotion film is: "August 10, 2020, tells about our experience in the Daily District of Samosir Regency. An experience that we will convey in visual greetings, as a form of searching for one's reality. A way of arranging memories in a country, which they call the piece of heaven. There is hope that we can find answers from the steps that have been taken so that it will be engraved in the heart which is always looking constantly. Come here I'm sure you can find the pieces. in a beautiful land of pieces of heaven".

\subsection{Mise-en-Scene Preparation}

Mise-en-scene has an urgent position in the making of this tourist film because it includes the setting, lighting, costumes, actor acting, and composition. For the background, filming was done to show the uniqueness of Lake Toba. This also applies to lighting settings, custom actors, and player actions. Based on the fact that this film is an observational documentary film, the setting applied in the field is a real display with a minimum of additional settings in the field.

\subsection{Preparation for Tourism Film Distribution}

The travel film is planned to be published on social media which has large followers or followers such as Medantalk, North Sumatra circumference, and USU children. This social media was chosen because of the target of prospective tourists who are expected to prioritize local tourists from North Sumatra, especially Medan City.

\subsection{Tourist Film Production}

The tourist film production in question is the application or application of all the initial planning of making films that have been determined during pre-production. The production of tourist films when in the field, such as: checking the suitability of film shooting with the concept of tourist films, shooting from predetermined tourist film locations, shooting focused on tourism activities, using recording equipment while at tourist sites, application of film scenarios Tourism at tourist sites, and application of mise-en-scene. Work indicators for tourist film production, such as Shot, are: 


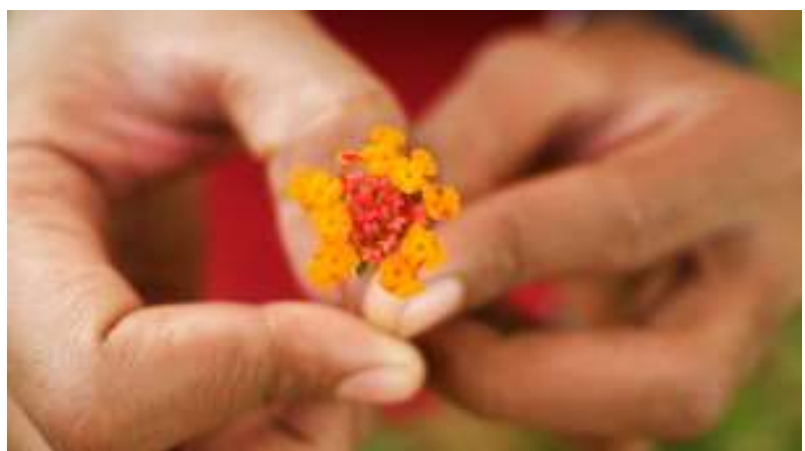

Figure 3. Extreme Close Up. Source: Personal Documentation

We use the shot type from Figure 3 as a complement to the film. The purpose and meaning of this shooting are so that visitors can see the symbol of the combination between nature and humans in the Lake Toba environment which is intended as a tourist location. The contours of the flowers represent nature and the contours of the hands represent humans who use nature to survive in the location of Lake Toba. Based on the interview, the Extreme Close Up type does not have a big effect on visitors when deciding to travel to this location. When traveling, visitors see the location extensively, it is rare for tourists to see tourist locations in detail like this except for research or having a specific purpose, because That's this type of shot that's minimal to do.
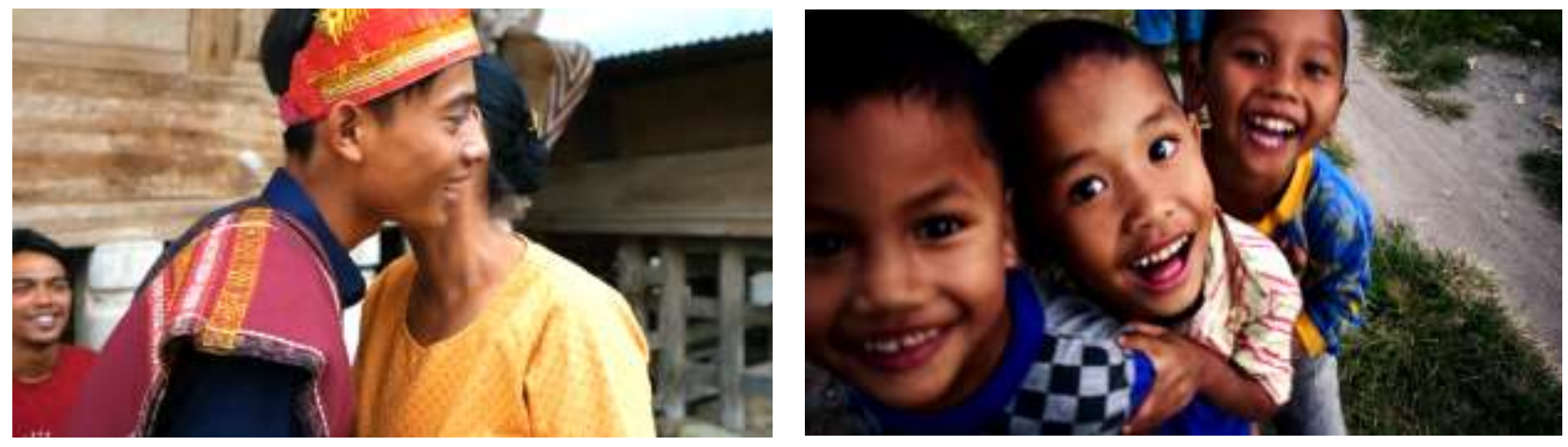

Figure 4. Medium Shot. Source: Personal Documentation

The shot type of figure 4 are used to illustrate the closeness of visitors and indigenous peoples so that visitors can feel a sense of hospitality from the host who welcomes visitors openly in their environment. The first picture is when visitors are given the title or clan of the indigenous people, that they are currently tied to one of the families who put the traditional cloth (ulos) on their right shoulder. The concept of kinship collaboration and tourism practices like this is still very rarely practiced anywhere in Indonesia. Guests who are given a clan from one of the families will feel that they have become part of the community or group so that they feel respect, a sense of belonging, a sense of responsibility towards the family that has given clan and maintains a culture capable of growing and developing. Based on the results of the interviews, this type greatly influences tourists to make the returning effect. The returning effect of the message generated in this film can certainly be a natural strategy that sends a message to potential tourists that sometimes travel is not just looking around but can create a new atmosphere, such as creating friends, friends, and family at tourist locations. which is aimed. Herein lies the benefit of the oral tradition that is featured in the film in the tourism chain which is mutually needed and bound. This type is very influential for tourists to make a return visit decision (returning effect). The returning effect of the message generated in this 
film can certainly be a natural strategy that sends a message to potential tourists that sometimes travel is not just looking around but can create a new atmosphere, such as creating friends, friends, and family at tourist locations which is aimed. Herein lies the benefit of the oral tradition that is featured in the film in the tourism chain which is mutually needed and bound. This type is very influential for tourists to make a return visit decision (returning effect). The returning effect of the message generated in this film can certainly be a natural strategy that sends a message to potential tourists that sometimes travel is not just looking around but can create a new atmosphere, such as creating friends, friends, and family at tourist locations which is aimed. Herein lies the benefit of the oral tradition that is featured in the film in the tourism chain which is mutually needed and bound. The returning effect of the message generated in this film can certainly be a natural strategy that sends a message to potential tourists that sometimes travel is not just looking around but can create a new atmosphere, such as creating friends, friends, and family at tourist locations which is aimed. Herein lies the benefit of the oral tradition that is featured in the film in the tourism chain which is mutually needed and bound. The returning effect of the message generated in this film can certainly be a natural strategy that sends a message to potential tourists that sometimes travel is not just looking around but can create a new atmosphere, such as creating friends, friends, and family at tourist locations which is aimed. Herein lies the benefit of the oral tradition that is featured in the film in the tourism chain which is mutually needed and bound.
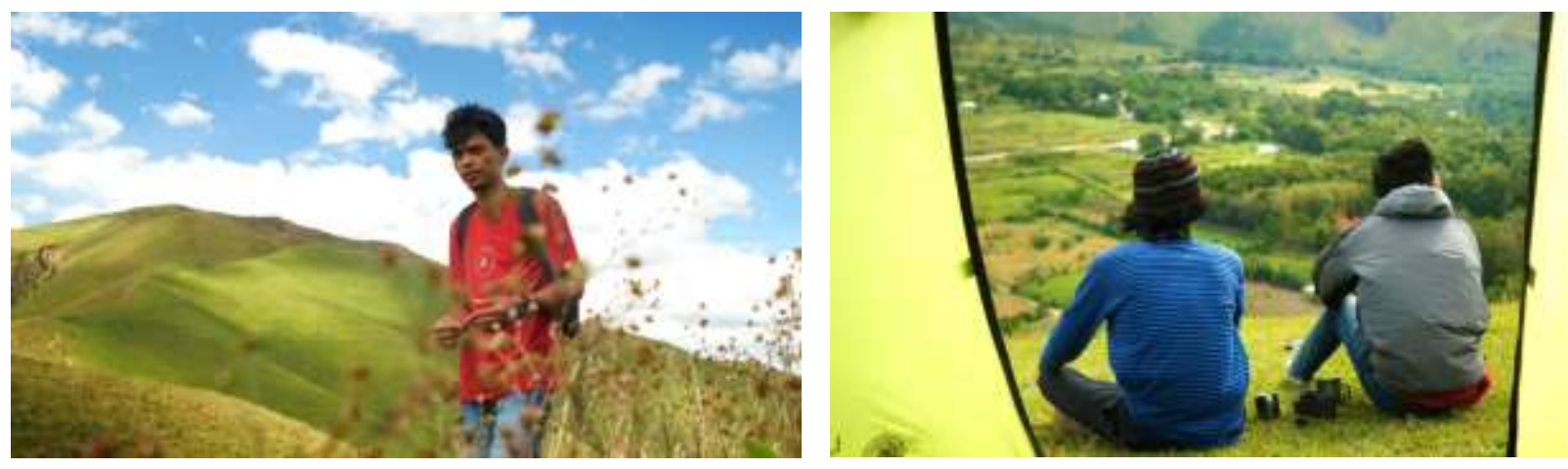

Figure 5. Medium Long Shot Source: Personal Documentation

The shot type of Figure 5 are used to show the closeness of humans to nature. Nearly $70 \%$ of the shot method is used in the production process. This type emphasizes to the audience that when visiting this location, tourists can feel serene and peaceful memories while this location is visited. Based on the results of interviews, this type has a very big influence on tourists in making travel decisions, with 2 opinions, namely: 1) want to feel the same atmosphere and sensation as in the film so that fatigue, boredom, and burdens are at the place of origin tourists, for example in a work environment or household environment, can immediately be distracted by natural conditions that are so calm;2) The urban and office environment that is often felt to be saturating, make tourists want to present a new atmosphere for their social media. tourists also want to take pictures with the same concept as the photo. This photo choice is a priority because if the photo is too close, the nature shown may not be visible, and if it is too far away, the netizen does not know who the subject is in the frame is taken. Based on the results of the interviews, this type is very influential for tourists to decide on traveling. 

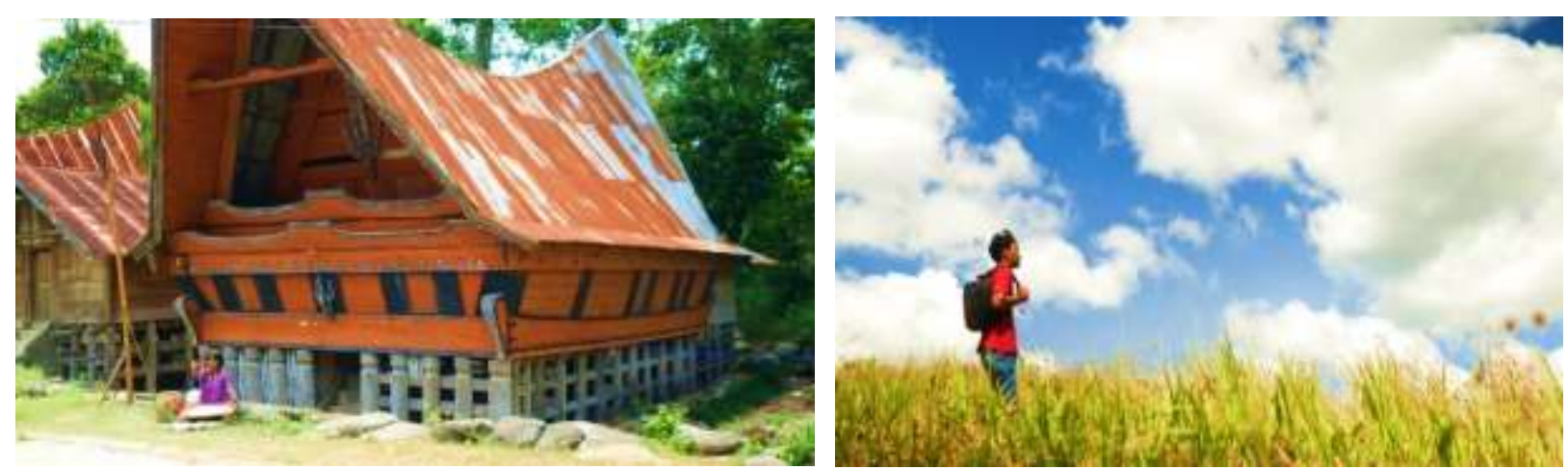

Figure 6. Long Shot Source: Personal Documentation

The shot type of figure 5 shows the collaborative feelings of the actor and his environment. This shot type is a type that almost displays the entire tourist location to be visited. This type provides information to visitors about the tourist location situation. Based on the results of the interview, this type has a big influence and can provide an image for tourists on visiting decisions as well as the type of tourism that fits the category they have. From this type of shot, tourists have the view that the backpacker type of adventure tourism is more suitable to be attached to this tourist location than other types of tourism. Based on the results of subsequent interviews, potential mass tourism tourists who generally depart using more than 2 large buses when visiting, are reluctant to visit this location.

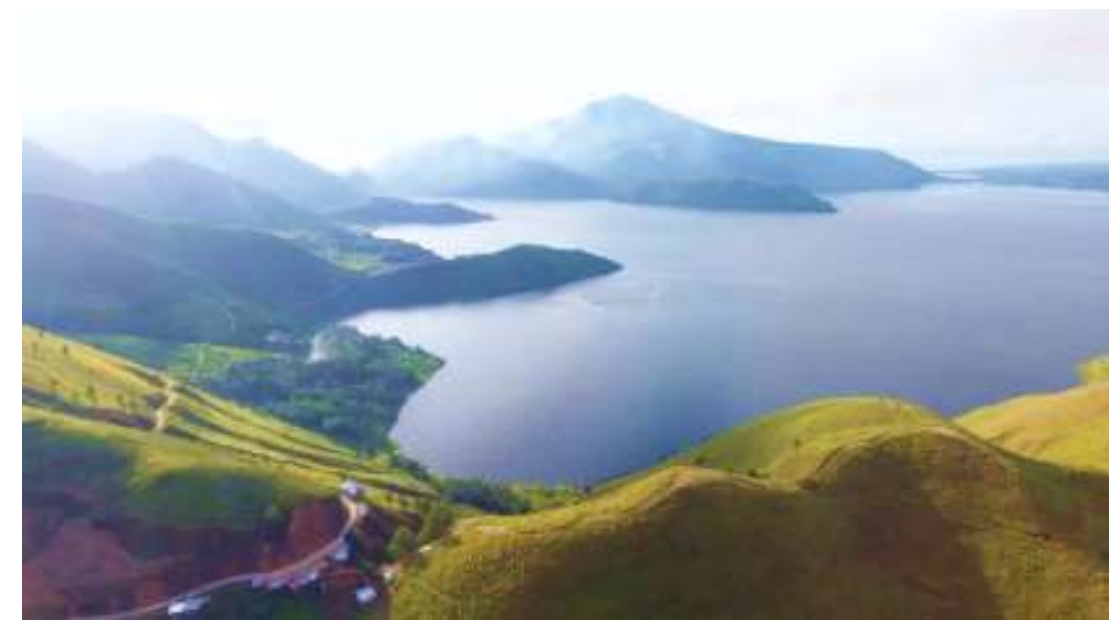

Figure 7. Establishing Shot Source: Personal Documentation

The shot type from Figure 7 is used to show the location to be visited. This type provides comprehensive information so that visitors are not miss-leading to the location visited. This type is mostly featured in films to show tourist locations more perfectly. According to the opinion of several potential visitors based on the appearance presented, this location has its challenges in terms of age, weight, and daily activities of visitors. This display gives visitors an idea of the tiring terrain for tourists who are not used to sports. With locations such as hills with long terrain, as well as hiking and downhill tracks, some visitors have to make physical preparations before arriving at this location. 

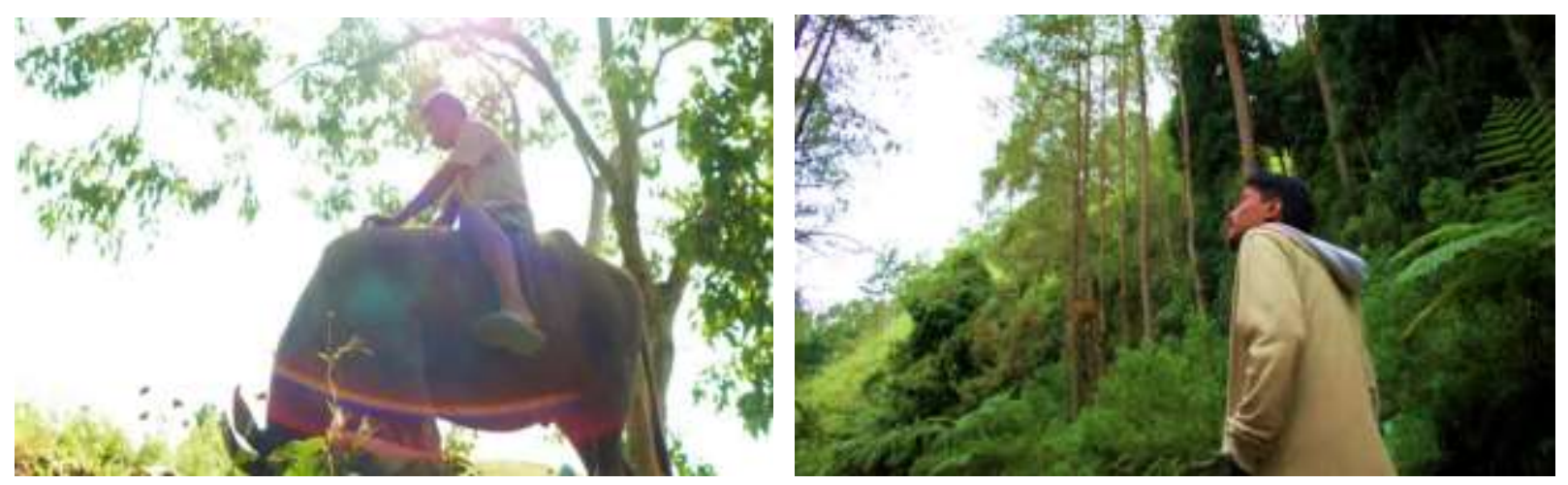

Figure 8. Frog eye level Source: Personal Documentation

Angle shot Figure 8 is used to explain to visitors the daily activities of the local community where one of them is herding buffalo because the theme of the film must also be related to adventure tourism with type backpacker tourism, this angle is also used to show the actor's travel process to arrive at this location. Based on the interview results, this type does not significantly influence tourists in making travel decisions, because it focuses heavily on the actors being shot, not showing the location but the actors' feelings in carrying out their activities.
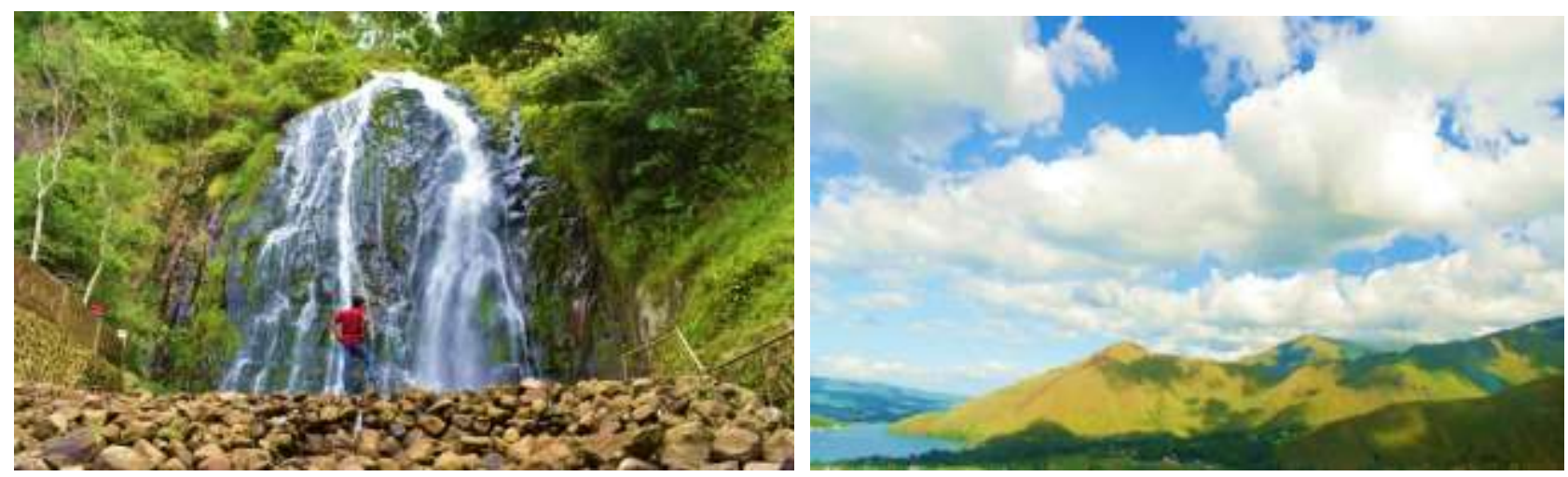

Figure 9. Low Angle Source: Personal Documentation

Angle shot Figure 9 are used to explain to the audience the full appearance of the tourist location. Based on the results of the interviews, this type is quite influential for tourists in making travel decisions. Some views of visitors state that the low angle is generally made to fulfill the cinematic element in the film.

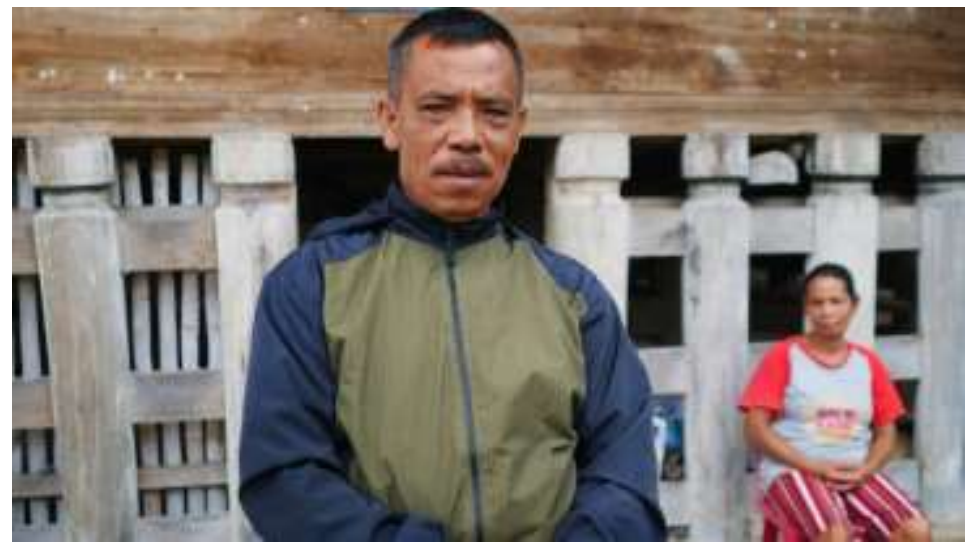

Figure 10. Eye-Level Source: Personal Documentation 
Angle shot Figure 10 is used to show stakeholders who are involved and responsible at the tourist site to potential tourists. Based on the results of the interviews, this type has a very big influence on tourists in making travel decisions, because the views and discourses conveyed by stakeholders are information that tourists need when visiting later. This scene conveys messages such as from lodging to consumption that will be given to tourists later, activities that will be provided for tourists, to cellphone contacts if tourists want to visit this location.

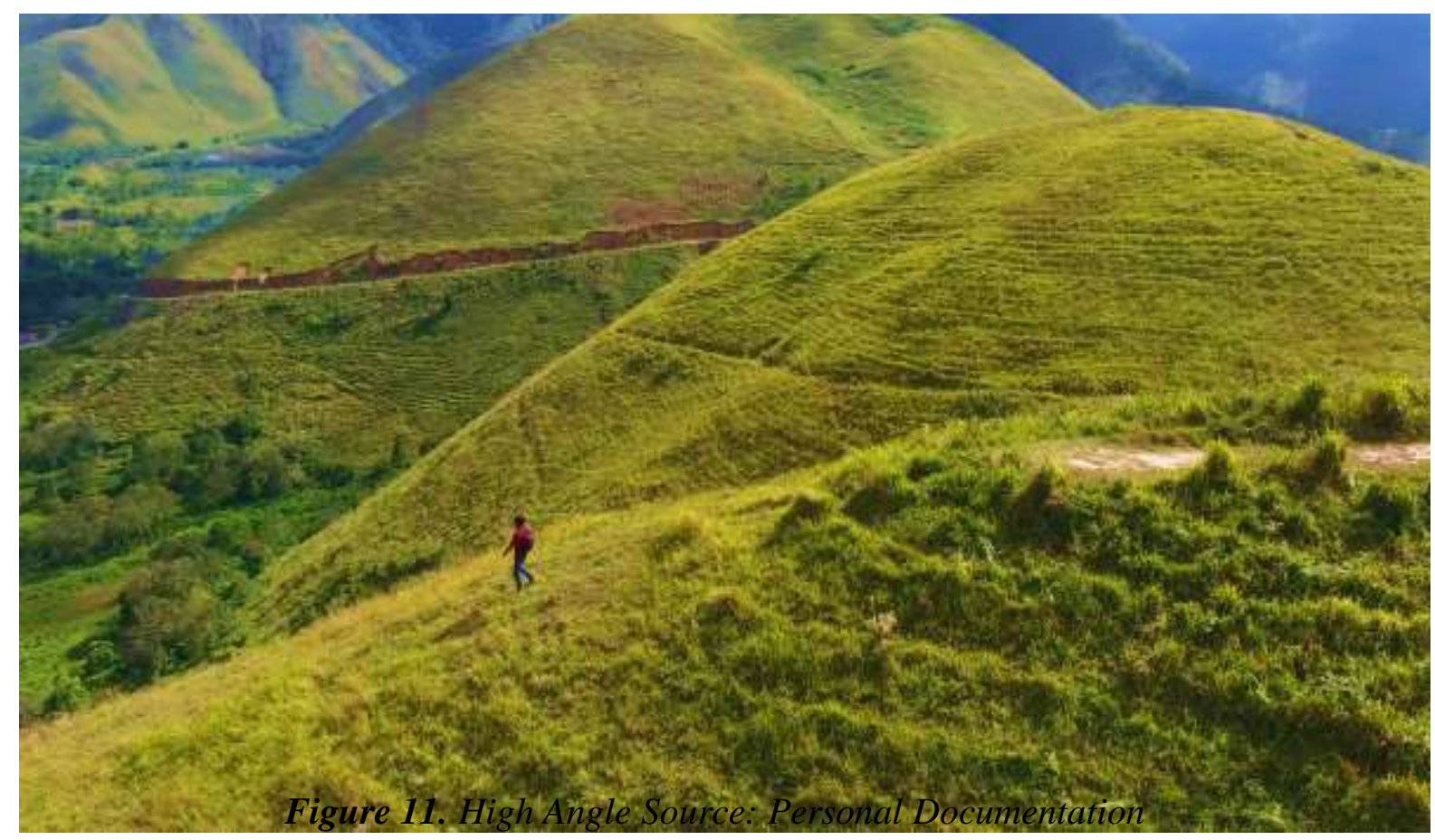

Angle shot from Figure 9, this is the type of angle that we prioritize in the production of an Instagramable travel film in the Boho Daily District. This is because the tourist film has the intention of 'reveal' or fully disclosing all potential tourist attractions in the tourist film. Based on the results of interviews, this type has a very big influence on tourists in making travel decisions, because the appearance can reveal the unique impression of the intended tourist destination.

\subsection{Post-Production Tourism Film}

Post-production of the tourist film is the final stage before finally the tourist film is widely distributed. Post-production travel film-making covers 2 aspects, namely video processing and audio processing. For video processing things that are done are:

Logging, in this process the editor enters all the shot results into a folder that has previously been separated by time and recording tools

Digitizing, the data that has been selected and arranged in a folder are then entered into Adobe Premiere Pro 2019 for processing. 


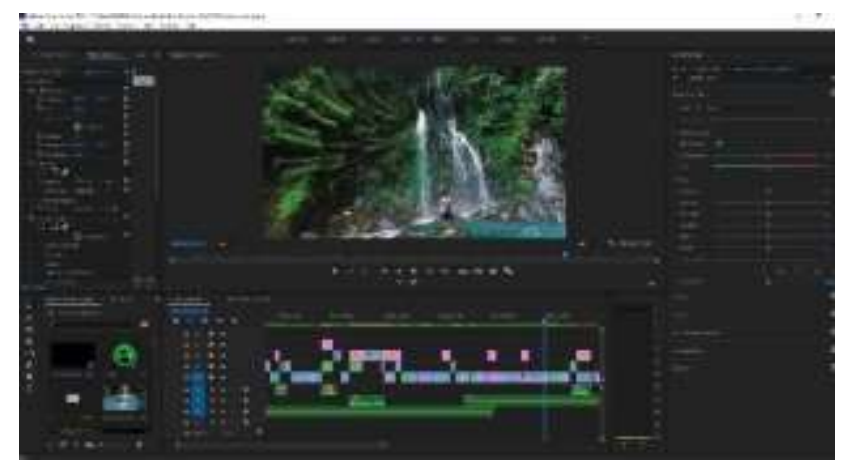

Figure 12. Video Production Post Process Source: Personal Documentation

Offline editing, the scenarios that have been read by stakeholders are then matched with videos that are related to the theme of the tourist film. Online editing, in this case, the editor then performs a process to refine the results of offline editing.

Mixing, two actions must be done, namely adjusting the sound level of the music with the voice of the actor who plays a role and adjusting the beat of the music used. For audio processing, what is done is to minimize the noise that arises from the natural environment of the Daily Boho District:

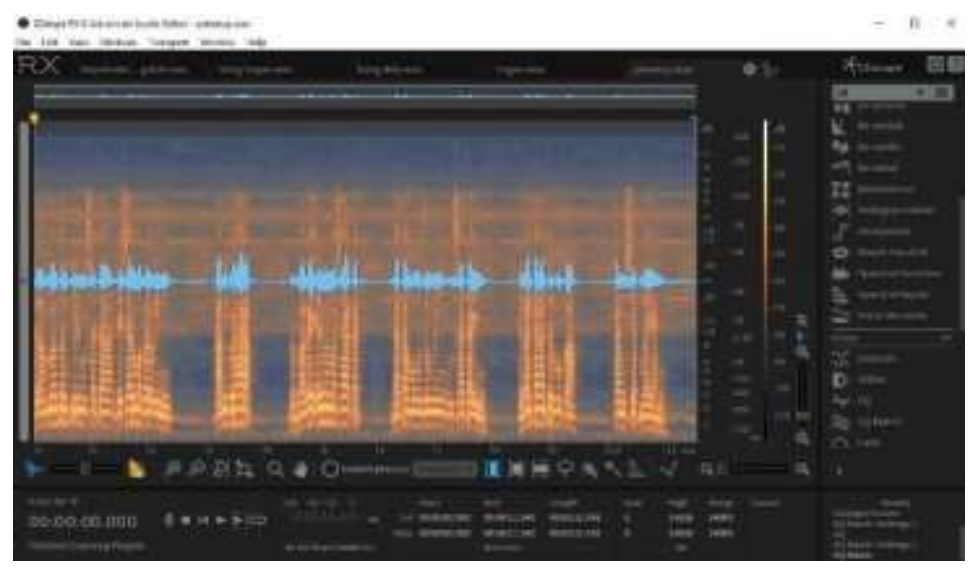

Figure 13. Audio Post Production Process Source: Personal Documentation

The priority parts of the application that are often used in the audio processing of travel films in the Boho Daily District are voice de-noise, dialogue isolate, and EQ.

\subsection{Validation of Instagramable Travel Films}

There are 4 indicators in Hasan's Theory (2015) that can be used in displaying instagramable tourist attractions in the film components that have been created:

1) Colors or images projected from travel films as instagramable media must be designed to attract the attention of tourists: the work indicators tested on travel films with the test elements are stakeholder views of film colors, messages from film images, and whether travel films can attract tourists' attention. Lack of public awareness in protecting their environment by burning which is often carried out, such as 1) when opening agricultural land, 2) burning hay that has been harvested, and 3) when cleaning fields from fast-growing weeds. This can result in a dramatic imbalance when tourists visit the site due to the fires that have occurred, Natural natural situations cannot be displayed in photos or videos that will be uploaded to the visitor's Instagram or social media. The following is a display of post-shot images carried out by the research team: 

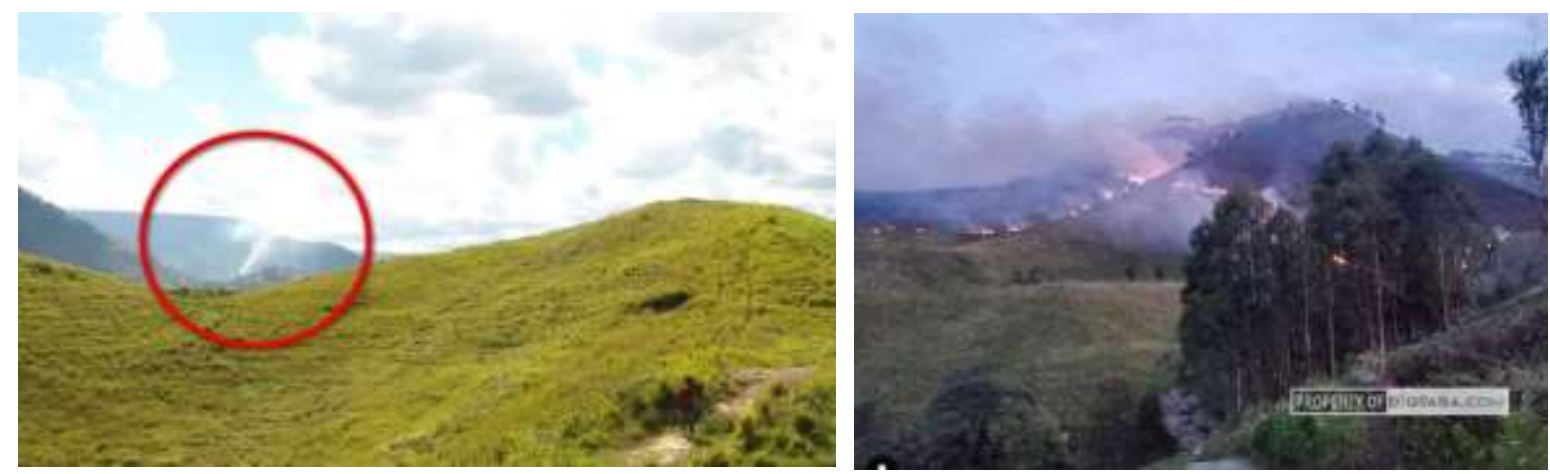

Figure 14. Display of the starting point of fire (left) when the team shot the location until it burned almost the entire hill (right). Source: Personal Documentation and www. digtara.com

Of course, this is not by the appearance of the tourist film presented so that it can make tourists disappointed and angry when visiting later. But apart from all that, have the colors or images of travel films been able to attract the attention of tourists? the result is correct, the color of the tourist film is made to attract the attention of tourists. The test is taken from the feedback or tourists' responses to the tourist films they have watched.

2).Instagrammable travel films must be able to display features that can strengthen the uniqueness of the image of a tourist destination through the film shooting feature. In presenting 'instagramable tourist destinations', travel films must be able to capture images from various kinds of shots and angles. The indicator is then tested against the film with the test element being the angle of the film shot. Instagramable travel films must fulfill a high element of creativity. So that the shooting point of view and the angle of the tourist film can display features that can strengthen the uniqueness of the image of a beautiful, cultured, and natural tourist destination.

3).An instagramable travel film must be able to show the multi-dimensional nature of the destination. This work indicator is then tested against the tourist film with the test element being the display of various tourist activities or activities that can be carried out at tourist sites. After tourists watch this film, all tourists do not know the variety of activities and tourism potentials hidden around the sub-district such as sarcophagi, community passenger ships around the lake for 5000 / person, and agricultural potential which received permission from local farmers to take pictures. at a sincere price. This received enthusiastic attention from all interview participants. From this film, all tourists are motivated to visit this tourist destination.

4). An Instagramable travel film must have a ratio of approximately $54 \%$ of tourist image views and $46 \%$ of tourist information. This work indicator is then tested against travel films with the testing elements being the effectiveness and time efficiency of the film in conveying tourist information. The stakeholder's response to this is that tourist films can provide images and tourist information that are very important for tourists.

From the test results of the four theoretical work indicators above, it can be seen that the tourist film that has been made is an instagramable and informative travel film for tourists who will visit Boho Daily District, Samosir Regency. 


\subsection{The Impact of Tourism Films on Tourist Visits when COVID-19 Takes Place}

After making the film, the film is then distributed to all social media based in North Sumatra. The selected social media accounts are 3 social media that are very influential in North Sumatra, especially Medan City such as Lingkar North Sumatra, Kalak Karo, and Travelmatesiantar. This publishing experiment was carried out starting from September to November 2020. The condition of tourism in all of Lake Toba's tourist destinations, which are currently heavily affected by the COVID-19 issue, with a tourist visit rate of almost $7 \%$ compared to the previous year, namely 178,000 visits to Lake Toba this year. 2019. This needs to be appropriately triggered to stimulate this level of visits. Through information and statistical data on tourist visits from the Boho Daily District tourism manager, from March 2020 to July 222020 the level of visits was only 10-15 people per week, wherein 2019, the level of tourist visits was able to reach over 2000 tourist visits per week or nearly 20,000 visitors per month during high season to Boho Daily District. The experiment was first carried out on August 29, then mid-September and early November 2020, namely the publishing of travel films to social media networks Instagram that has been determined, and is planned to end in November 2020.

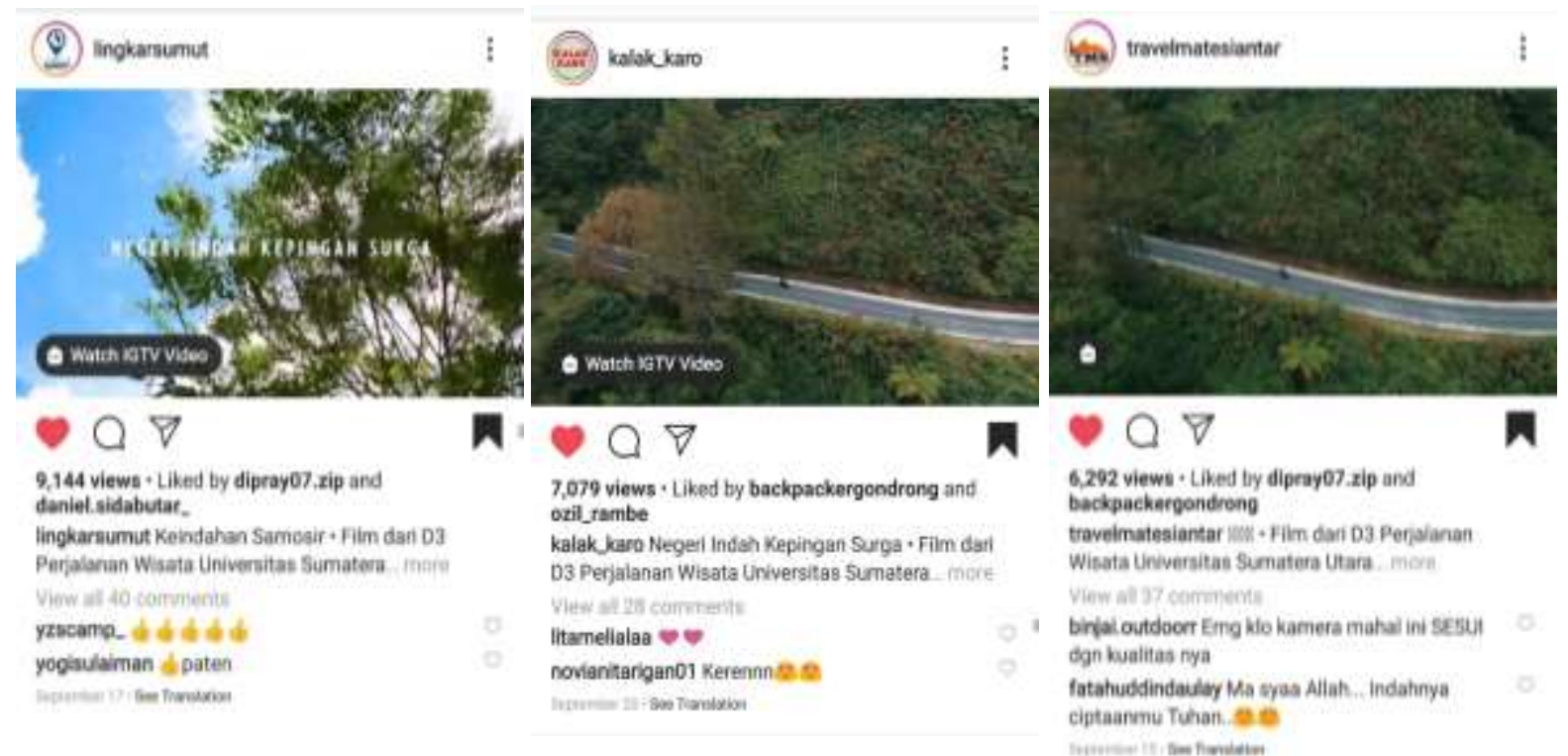

Figure 15. Number of Viewers of Tourism Film Publications

The results of the impact of publishing tourist films on the increase in tourist visits with a comparison in July 2020, namely only 22 tourists and even those who are relatives of residents who do have family in that location. After the Tourism Promotion Film was published, the tourist visit rate in August increased by 1,648 visits or an increase of $74.90 \%$ compared to the previous month (with the highest visit rate for 6 consecutive days before, during, and after the implementation of Indonesia's independence day. This significant increase occurred because These tourists think that the Lake Toba area is still in a LockDown condition, but after the screening of the film, tourists finally know that the Lake Toba location has opened the LockDown period. Then in September, it was recorded 1.876 visits or an increase of $1.13 \%$ from the previous month. In September there were 2,381 tourist visits, an increase of $1.26 \%$ from the previous month. The level of tourist visits in November was recorded at 2,456 or $1.03 \%$ of tourist visits from the previous month. From this experiment, it can be proven that Tourism Film has a significant effect on increasing tourist visits at a tourist location. 


\section{Conclusion}

In making tourism films as a tourism promotion media in the Boho Daily District, Langkat Regency, several things must be considered, namely 1) the process of making the tourism film itself and 2) validation which proves that the tourism film made is indeed a tourist film that is intended as a tourism film promotion media. The tourist film-making process covers pre-production, production to post-production; The most important thing from the three work indicators is pre-production because it covers all technical planning in the shooting tourist attraction. The pre-production of tourism films in the Boho Daily District starts with (1) designing the concept of tourism films, (2) determining the location of tourist films, (3) determining activities, (4) tourism facilities and services at tourist film locations, (5) determining tools film recording and editing tools, (6) preparation of tourist film scenarios (cinematography), and (7) preparation of mise-en-scene. These seven things are the main tasks that must be carried out at the time of production to post-production of films, while the validation of travel films as promotional media includes: (1) color or film images: where the test element is the stakeholder's view of the colors and messages of the film images, The results of the study reveal that of the 10 tourists who have watched tourist films, all of them think that tourist films can attract tourists to visit, (2) Tourism films as promotional media must display features that can strengthen the uniqueness of the image of a tourist destination: with the testing element is the angle. field shooting film. From the test results, it is revealed that the point of view of tourist film shots can strengthen the uniqueness of the image of the Boho Daily District as a beautiful and natural tourist destination. or tourist activities that can be carried out at tourist sites. From the results of the test, it was revealed from the stakeholder's response to this, namely that the tourism film was able to show a variety of tourism activities such as jungle tracking, viewing waterfalls and body rafting, (4) and the ratio of 54\% displaying images and $46 \%$ of information: with the testing element is effectiveness. And film time efficiency in conveying tourist information.

\section{Acknowledgment}

I would like to acknowledge the research Institute Universitas Sumatera Utara, the assistance of my staff, informant, and colleagues who help me in finishing this paper.

\section{References}

Amin, M et al. (2019). Marketing Communication Strategy To Improve Tourism Potential. Budapest International Research and Critics Institute-Journal (BIRCI-Journal). P. 160166.

Budiyanti, E. (2020). Dampak virus corona terhadap sektor perdagangan dan pariwisata Indonesia. Kajian Singkat Terhadap Isu Aktual dan Strategis, 12(4), 19-24.

Beeton, Sue. (2010). The Advance of Film Tourism. Tourism and Hospitality Planning \& Development. 7. 1-6. 10.1080/14790530903522572.

Brata, Vincent Bayu Tapa. (2007). Videografi dan sinematografi praktis. Jakarta: PT. Elex Media Komputindo.

Campbell, Eric and Lisa McGregor. (2020). These five strategies have helped Singapore fight off the coronavirus outbreak. Can they keep it at bay?. Retrieved Mar 31, 2020 from https://www.abc.net.au/news/2020-03-31/coronavirus-singapore-how-it-fought-thevirus/12100072 
Hasan, Ali. (2015). Tourism marketing. Yogyakarta: CAPS (Center of Academic Publishing Service).

Hudson, S., Ritchie, J. B. (2005). Film tourism and destination marketing: the case of captain corelli's mandolin. Journal of Vacation Marketing, Vol. 12 (3), p. 256-268.

Irawan, Etsa Indra. (2011). Sinematografi (panduan usaha mandiri). Bandung: Yrama Widya.

Nurlina, (2020). Tourism Development in Langsa, Indonesia: An Overview of Tourist Attractions and Accommodation. Budapest International Research and Critics InstituteJournal (BIRCI-Journal). P.923-931

OECD. (2020). OECD interim economic assessment Coronavirus: the world economy at risk. Retrieved March 2, 2020, from https://www.oecd.org/berlin/publikationen/InterimEconomic-Assessment-2-March2020.pdf

Pemerintah Indonesia. (2009). Undang-Undang No. 10 Tahun 2009 tentang kepariwisataan. Kementerian Pariwisata dan Ekonomi Kreatif.

Pemerintah Indonesia. (2009). Undang-Undang Republik Indonesia Nomor 33 Tahun 2009 Tentang Perfilman. Presiden Republik Indonesia.

Pemerintah Indonesia. (2015). Laporan Akuntabilitas Kinerja Kementerian Pariwisata tahun 2015. Kementerian Pariwisata dan Ekonomi Kreatif.

Pemerintah Indonesia. (2017). Peraturan Menteri Dalam Negeri Republik Indonesia Nomor 3 Tahun 2017. Kementerian Dalam Negeri dan Pemerintahan Daerah.

Sen, Siow Li. (2020). Singapore currency to stay strong until 2021 on broad USD weakness. Retrieved AUG 25, 2020 from https://www.businesstimes.com.sg/bankingfinance/singapore-currency-to-stay-strong-until-2021-on-broad-usd-weakness

Semedhi, Bambang. (2011). Sinematografi-videografi suatu pengantar. Bogor: Penerbit Ghalia Indonesia.

Sinulingga, Samerdanta \& Pardosi, Jhonson \& Bangun, Nur \& Siahaan, Hotlan. (2020). Pembuatan Film Wisata Sebagai Media Promosi Pariwisata di Desa Rumah Galuh $\begin{array}{lllll}\text { Kabupaten Langkat. Jurnal Master Pariwisata (JUMPA). } 350 . & 35 .\end{array}$ 10.24843/JUMPA.2020.v06.i02.p06.

Siregar, Rizky \& Wiranegara, Hanny \& Hermantoro, Henky. (2018). Pengembangan Kawasan Pariwisata Danau Toba, Kabupaten Toba Samosir. Tataloka. 20.100. 10.14710/tataloka.20.2.100-112.

Suryajaya, Minghadi. (2018). Wonderful indonesia revolusi tour \& travel digital. Jakarta: Elex Media Komputindo.

Wardani, Mentari \& Nasution, Nur. (2016). Kontribusi Pengembangan Pariwisata Danau Toba Melalui Skema Bop (Badan Otorita Pariwisata) Bagi Masyarakat Di Sekitar Danau Toba. Call for Paper FW Great Event 2016.

World Tourism Organization. (2020). Impact assessment of the Covid-19 outbreak on international tourism. Retrieved March 27, 2020, from https://www.unwto.org/sites/default/files/news/un-tourism-news-10.html

Yusuf, A. Muri. (2013). Metode Penelitian (Kuantitatif, Kualitatif, Penelitian Gabungan). Jakarta: Prenadamedia Group. 